UDC 78.03+782.1

DOI https://doi.org/10.31723/2524-0447-2020-30-2-24

Du Wei

ORCID: 0000-0003-3399-4278

Applicant at the Department of Music History and Musical Ethnography

Odessa National A. V. Nezhdanova Academy of Music

WeiduOd19@gmail.com

\title{
THE INFLUENCE OF THE ARTISTIC PRINCIPLES OF THE XIX CENTURY RUSSIAN ROMANCE ON THE CHAMBER AND VOCAL WORK OF S. SLONIMSKY: TRADITIONS AND INNOVATION
}

The aim of the article is to study the chamber and vocal work of S. Slonimsky, highlighting the structural and compositional principles of their structure, as well as tracing the relationship with the formative principles and artistic techniques of the Russian romance of the XIX century. The methodology of the work is determined by the unity of genre and style, comparative historical, musicological, analytical, semantic and intonational approaches, which allows to develop a comprehensive interdisciplinary research framework. The bright individuality and innovation of artistic ideas, the unique stylistic originality of S. Slonimsky's musical language predetermined the search for an adequate research methodology lying at the junction of various humanitarian scientific directions, since the creation of a single interdisciplinary basis expands the scope of ideas about the possibilities of complex art history analysis. The scientific novelty lies in the examination of the chamber and vocal work of S. Slonimsky in the context of the general evolution of the musical-historical process with the establishment of close ties with the traditions of the Russian romance of the XIX century.

Conclusions. Structural and compositional parameters and principles of the organization of musical material in the chamber and vocal work of $S$. Slonimsky also reveal a close connection with the traditions of the formation of Russian classical romance of the XIX century. The most widespread method of organizing Slonimsky's vocal lyrics is the use of the principle of a varied stanza, which is dominant in all chamber and vocal compositions of the composer. In a number of S. Slonimsky's romances, one can find the characteristic features of Russian "urban" lyrics of the early XIX century, including moving away from following a strictly regulated couplet structure, which is achieved through the appearance of recitative elements in the last stanza with a refusal of the couplet development of melodic material.

Key words: chamber and vocal work, Russian romance, vocal intonation, speech intonation, cultural memory. 
Ду Вей, здобувач кафедри історії музики та музичної етнографіі Одеської національної музичної академії імені А. В. Нежданової

Вилив художніх принщипів російського романсу XIX століття на камерно-вокальну твориість С. Слонімського: традиції та новаторство

Метою статті є вивчення камерно-вокальної творчості С. Слонімського з виділенням структурно-композиційних принципів їх будови, а також простеження взаємозв'язків з формотворними принципами $i$ художніми прийомами російського романсу ХІХ століття. Методологія роботи визначається єдністю жанрово-стильового, порівняльного історичного, музикознавчого аналітичного, семантичного та інтонаційного підходів, що дозволяє виробляти комплексну міждисииплінарну основу дослідження. Яскрава індивідуальність і новаторство художніх ідей, унікальна стильова самобутність музичної мови С. Слонімського визначили пошук адекватної дослідницької методології, що лежить на стику різних гуманітарних наукових напрямів, оскільки створення єдиної міждисциплінарної основи розширюе сферу уявлень про можлливості комплексного мистеитвознавчого аналізу. Наукова новизна полягає в розгляді камерно-вокальної творчості С. Слонімського в контексті загальної еволюиії музично-історичного процесу з встановленням тісних зв'язків з традиціями російського романсу ХІХ століття. Висновки. Структурно-композиційні параметри і принципи організаціі музичного матеріалу в камерно-вокальній творчості С. Слонімського виявляють тісний зв'язок з традиціями формоутворення російського класичного романсу ХІХ століття. Найбільш поширеним прийомом організації вокальної лірики Слонімського стає використання принципу варіюйованої строфи, який є домінуючим у всіх камерно-вокальних творах композитора. У низиі романсів С. Слонімського можна виявити характерні особливості російської «міської» лірики початку ХІХ століття, в тому числі відхід від дотримання строго регламентованої куплетної структури, що досягається за допомогою появи в останній строфі речитативних елементів з відмовою від куплетного розвитку мелодійного матеріалу.

Ключові слова: камерно-вокальна творчість, російський романс, вокальне інтонування, мовна інтонація, пам'ять культури.

Ду Вей, соискатель кафедры истории музыки и музыкальной этнографии Одесской национальной музыкальной академии имени А. В. Неждановой

Влияние художественных принципов русского романса XIX века на камерно-вокальное твориество С. Слонимского: традищи и новаторство

Целью статьи является изучение камерно-вокального творчества C. Слонимского с выделением структурно-композиционных принципов их строения, а также прослеживания взаимосвязей с формообразующими принципами и художественными приемами русского романса ХІХ века. Методология работы определяется единством жанрово-стилевого, сравнительного исторического, музыковедческого аналитического, семантического и интонационного подходов, что позволяет выраба- 
тывать комплексную междисииллинарную основу исследования. Яркая индивидуальность и новаторство художественных идей, уникальная стилевая самобытность музыкального языка С. Слонимского предопределили поиск адекватной исследовательской методологии, лежащей на стыке различных гуманитарных научных направлений, так как создание единой междисииплинарной основы расширяет сферу представлений о возможностях комплексного искусствоведческого анализа. Научная новизна заключается в рассмотрении камерно-вокального творчества C. Слонимского в контексте общей эволюции музыкально-исторического процесса с установлением тесных связей с традициями русского романса ХІХ века. Выводы. Структурно-композиционные параметры и принципы организации музыкального материала в камерно-вокальном творчестве С. Слонимского обнаруживают тесную связь с традициями формообразования русского классического романса ХІХ столетия. Наиболее распространенным приемом организации вокальной лирики Слонимского становится использование принципа варьированной строфы, который является доминирующим по всех камерно-вокальных сочинениях композитора. В ряде романсов С. Слонимского можно обнаружить характерные особенности русской «городской» лирики начала ХІХ века, в том числе отход от следования строго регламентированной куплетной структуре, что достигается при помощи появления в последней строфе речитативных элементов с отказом от куплетного развития мелодического материала.

Ключевые слова: камерно-вокальное творчество, русский романс, вокальное интонирование, речевая интонация, память культуры.

Relevance. In the musical culture of the second half of the XX - beginning of the XXI century, the work of Sergei Slonimsky occupies a special place. Starting from the 60s of the last century and up to the last years of his life, the composer created compositions that rightfully took their place among the outstanding works of our time. The special significance of S. Slonimsky's work in modern musical culture is confirmed by numerous musicological studies - from large-scale monographs to short scientific essays. The greatest attention is attracted by the unique musical language of the composer and special compositional and technological techniques that make it possible to distinguish the composer's style as a unique phenomenon in modern musical culture.

The inner nature of the creative personality of Slonimsky, the bright originality and individuality of his musical language, on the one hand, opened up fundamentally new opportunities for the evolution of modern musical art. On the other hand, they became the connecting thread between musical and aesthetic traditions and artistic and stylistic principles of the past. When considering the 
works of S. Slonimsky in all their genre diversity, it becomes obvious that in general it is a complex, ramified, multi-level, and, at the same time, an integral system. In this regard, the identification of the support of S. Slonimsky's composer's method on the internal logic and structural and compositional principles of the works of his great predecessors makes it possible to discover the laws of the internal organization and structure of his entire musical system.

The aim of the article is to study the chamber and vocal work of S. Slonimsky, highlighting the structural and compositional principles of their structure, as well as tracing the relationship with the formative principles and artistic techniques of the Russian romance of the XIX century. The methodology of the work is determined by the unity of genre and style, comparative historical, musicological, analytical, semantic and intonational approaches, which allows to develop a comprehensive interdisciplinary research framework. The bright individuality and innovation of artistic ideas, the unique stylistic originality of S. Slonimsky's musical language predetermined the search for an adequate research methodology lying at the junction of various humanitarian scientific directions, since the creation of a single interdisciplinary basis expands the scope of ideas about the possibilities of complex art history analysis.

The scientific novelty lies in the examination of the chamber and vocal work of S. Slonimsky in the context of the general evolution of the musical-historical process with the establishment of close ties with the traditions of the Russian romance of the XIX century.

Review of the literature on the problem. Among the studies devoted to the general issues of S. Slonimsky's works there are monographic and dissertation research by A. Milka, M. Rytsareva, V. Marik, O. Devyatova, L. Gavrilova, A. Sapsovich and many others. At the same time, the composer's chamber and vocal work has not yet received sufficient attention, although a number of articles address the issues of the characteristic features of intonation in vocal compositions, including the "neo-folklore" direction (in articles by E. Ruchievskaya, L. Ivanova).

Presenting the main material. Despite a large number of symphonic, opera, cantata-oratorio opuses, which are vivid representatives of the individual style of S. Slonimsky, the composer's chamber and vocal work is one of the most significant and interesting in terms of stylistic decisions sphere in the composer's work. The composer turned to the chamber and vocal genre sphere through- 
out his entire career, paying special attention to the correlation of its verbal and musical components, the principles of correspondence between verse and musical metric structures.

In many literary studies, it is noted that the metric and compositional laws inherent in a poetic text have direct analogies with the structural principles of the metric of a musical text. It is known, for example, that a poetic meter with an even change of stressed and unstressed syllables is similar to a musical meter, which is determined by the regular alternation of strong and weak beats. The musicological works of $\mathrm{V}$. Vasina-Grossman are devoted to the questions of the transformation of the poetic word and the metric structure of the verse in chamber and vocal music $[1 ; 2 ; 3]$, E. Ruchievskaya $[8 ; 9]$ and others, which indicate that since vocal music is inextricably linked not only with the figurative and semantic series of poetry, but also with the embodiment of poetic structures, the priority task is to develop the principles of structural analysis of the chamber and vocal genre.

Based on the existing developments in literary criticism, the researchers draw analogies between metric verse and music, which made it possible to propose their own analytical method, which is based on the ratio of the poetic and musical structural levels, considered from different positions and highlighting different aspects of the phenomenon (metric, syntactic, compositional, phonic).

Many reflections of the composer himself, including on the expressive means of music, are extremely important in the study of the chamber and vocal work of S. Slonimsky. S. Slonimsky builds a kind of hierarchy among them, ranking them according to the accessibility scale. The most elementary means, the understanding of which does not require special skills and training, Slonimsky considers timbre, rhythm is more complex, and the melodic line crowns this whole structure. These means are, in his opinion, "almost the main, the most accessible, and by no means a melody, as it was thought before" [10, p. 25]. Slonimsky substantiates his statement by the special character of the melody perception, pointing out the peculiarities of melodic material of various origins and different levels of artistry - "if it is simple and elementary, if it completely depends on the rhythm and is dominated by the timbre of electric guitars, it is perceived. And a kind of long, modal-fresh developing melos (not to mention a complex of conjugate lines, vocal layers), as it turns out, is the most difficult thing for perception, requiring a highly organized intellect. So, the melody is far 
from the simplest and most intelligible in music from the point of view of reflex perception" [10, p. 25-26].

An important prerequisite for understanding S. Slonimsky's approach to the phenomenon of melodicism is the desire to compare the expressive possibilities of melody with the characteristic intonational expressiveness of human speech. The composer has repeatedly expressed concern over the total dominance of impersonal expressions and stereotyped phrases that make speech intonation devoid of its individuality and uniqueness. S. Slonimsky pointed out that such clichŭd statements "are not only vague in meaning, but also emotionally, intonationally impersonal, amorphous". In addition to the lack of uniqueness and individuality in such expressions, the composer emphasized another extremely important aspect of the problem - these expressions and short statements are absolutely impossible to sing, since "they are absolutely not singable". S. Slonimsky saw a particular danger in the dissemination of such speech constructs in the fact that "clogging up both everyday speech and solemn ceremonies, these words have a detrimental effect on the intonational atmosphere of human communication, accustoming people to cold non-contact and scary neutrality of language and tone. And this is serious, although outwardly imperceptible, it is also transformed by the musical and everyday element. It clearly loses warm, sincere vernacular, actively absorbing and highlighting its surrogates: feigned sentimentality, hysterical pathos, sugary sensuality - and all this with an internal rigid rhythmic and timbre grid (all the same, as they say, "uniqueness")" [11, p. 9-10].

According to S. Slonimsky, in the very essence of music, one can consider the expression of the human soul: "For me, the essence of music lies in the fact that in it, actually, the human soul comes to the surface. If a person does not feel the soul in himself and does not believe that he and other people have it, then this is no longer a person. And if there is no soul in it, then there is no music in it either" [4, p. 165]. Of all the arts, it was in music that the ability to express the movements of the soul acquired the greatest strength - "if a person has a soul and he is a creative person, then it is the soul that becomes transparent in music and comes to the surface of being more than in any other art - is it vocal music or instrumental. There is no difference here" [4, p. 165].

Studying the special properties of musical art, S. Slonimsky repeatedly noted the cultural significance and importance of the 
phenomenon of memory, which is an integral part of the problem of "connection of times", "continuity of generations" and, more broadly, cultural traditions and their development and renewal.

As S. Osadchaya points out in her works, the phenomenon of culture appears to be subordinate to the functions of memory, since culture is a complex system for storing and transmitting information. Culture not only preserves the necessary information, but also forms the most convenient and effective forms for this, allowing not only to preserve and transfer some cultural information, resorting to special coding systems for this, but also to transform messages and develop new ones. Thus, just acting as a form of collective memory, culture reaches the level of symbolization that allows expressing the constant antinomies of human existence - "oblivion-preservation", "finite-eternal", "death-immortality" [7, p. 100-101].

The phenomenon of memory of culture and culture as memory leads to the need to discuss the problem of tradition and innovation, which in the works of S. Slonimsky are based on the role of Russian culture as a whole, as well as on its influence on modernity. He pointed to the importance for him as a composer, and as for a creative individual of understanding the essence of the concept of national tradition, which cannot be "superficially, in a hurry to define" because "there is no doubt that modern music connects a lot with it" [6, p. 298]. In such a large-scale historical and cultural awareness of national traditions, the composer in his own way approaches the ideas of L. Gumilyov, who wrote about the complex and rich ethnic nature of the Russian people and the nature of cultural ties [5]. It is no coincidence that the composer mentions in this connection the name of the great Glinka, who really managed to cover a truly wide spectrum of ethnically different musical traditions. Reflecting on the traditions of Russian music, Slonimsky emphasizes its connection with folklore, rightfully assigning an almost dominant role to Mussorgsky.

In his perception of the traditions of Russian culture, Slonimsky is guided by the idea of the need for their "genuine continuation and renewal", which he associates with the composer's ability to "... find in each case some acutely relevant (in a good sense of the word), painful knot of current interest, an artistic problem that can be solved by musical means" [6, p. 301]. As an example, Slonimsky cites the works of outstanding composers of the XX century - 
S. Prokofiev and D. Shostakovich, who not only renewed the traditions of the past, but also formed their own tradition in the culture of the XX century. Slonimsky sees the essence of this process in the fact that "the artistic impression through which we perceive the tradition should be, first of all, fundamentally new in relation to what was heard earlier and at the same time organically connected with it". And in this process of developing traditions and creating new ones for Slonimsky, the most important condition is "high composer's skill", which, in his opinion, "is usually little taken into account” [6, p. 302-303].

Revealing the connections between the chamber and vocal works of S. Slonimsky and the traditions of the Russian romance of the XIX century, it is necessary to highlight a number of their structural and compositional features based on the organization of the verbal and poetic level. As you know, chamber and vocal lyric poetry of the XIX century, mainly used poetic texts of the syllabo-tonic versification system. As a result, this type of verse organization becomes the basis for identifying the methods of vocal transformation of the text. This is all the more justified, as in the chamber and vocal lyrics of S. Slonimsky, mainly syllabo-tonic or preserving in general the structural basis of syllabo-tonic verse poems were embodied. When considering the types of verse organization in a chamber and vocal composition of the XIX century, it should be noted that the unification of both the XIX and XX centuries into a single systematization of the Russian romance seems to be difficult to resolve, since the composers of the last century do not copy the techniques of the XIX century, but only start from them as from some general principles that become prototypes for individual and innovative methods.

The definition of the organization types of the poetic word in the chamber and vocal cycle is based on the research of E. Ruchievskaya [8; 9], which propose a system of principles for vocalizing a poetic text. The reliance on this system allows analyzing chamber and vocal genres in the inseparable unity of the poetic word and its musical embodiment. When analyzing the ratio of the verbal and musical levels in a chamber and vocal composition, which will reveal the types of organization of the poetic word, attention should be paid to the following parameters: the ratio of the metric structure of the verse and accent in music, the correspondence of the syntactic division of verse and music, the ratio of the syllables of the verse and the tones of the vocal line. 
Drawing parallels between the creative method of S. Slonimsky and the traditions of the Russian romance of the XIX century, it should be noted that for the poetic word of the XIX century, the rhythm, as a rule, obeyed the meter and only in some cases it was possible to observe a weakening of the uniformity of the appearance of metric accents of the feet, which led to an increase of the role of phrasal stress in a string. This laid the foundations for the perception of the poetic line as an integral structure, dominating in the poetry of the XX century. Within the framework of our research, this seems to be especially significant, since the main poetic material that S. Slonimsky used in his chamber and vocal work was the poetic opuses of S. Yesenin, F. Tyutchev, A. Koltsov, O. Mandelstam, M. Tsvetaeva, B. Akhmadulina, A. Gorodnitsky and others. Throughout the entire career of S. Slonimsky, the reference to the poetry of these authors in the cycles of romances and songs is a stable feature of the circle of his creative interests.

In the work of the composer there were periods of special attention to acutely innovative tendencies, with the inclusion of the newest techniques of composition, but at the same time S. Slonimsky considered it important for himself to continue working in the field of romance lyrics, without interrupting the connection with the traditions of the past. In one of his interviews, the composer pointed out that over time he developed his own "free musical language", the finding of which was quite difficult: "I was looking for it, I found it with painful difficulty, and now I have it even wider than then, in youth. Once I found musical language within the archaic, I would say, peasant archaic (for example, in "Songs of a Freeman"), but outside it turned out something wrong, not my own, or it didn't work at all. Now I do not shy away from any urban genre (and not necessarily in a grotesque refraction), I do not shy away from romance, where I can also say my word. It is believed, for example, that Sviridov and Gavrilin have their own specific style in the genre of romance. I have the right to say that romances based on Akhmatova's poems are not less popular, they also have their own stylistics, while this is not a stylization at all, but this is a genre of romance" [12, p. 229].

Further, the composer himself pointed out that his cycles of romances and songs are often direct continuators of the traditions of romance lyrics by $\mathrm{M}$. Balakirev and M. Glinka and others. He considered the opportunity to refer to this material extremely important, since the traditions of romance lyrics allowed him to 
discover new facets of his own musical language - "now I have a wider palette, a wider vocabulary, and musical language is not so narrowly individualized. I can find something of my own in a much broader sphere - both genre and style, and most importantly, figurative" [12, p. 229].

Conclusions. Structural and compositional parameters and principles of the organization of musical material in the chamber and vocal work of S. Slonimsky also reveal a close connection with the traditions of the formation of Russian classical romance of the XIX century. The most widespread method of organizing Slonimsky's vocal lyrics is the use of the principle of a varied stanza, which is dominant in all chamber and vocal compositions of the composer. In a number of S. Slonimsky's romances, one can find the characteristic features of Russian "urban" lyrics of the early XIX century, including moving away from following a strictly regulated couplet structure, which is achieved through the appearance of recitative elements in the last stanza with a refusal of the couplet development of melodic material.

A characteristic feature of the formation of chamber and vocal compositions by $\mathrm{S}$. Slonimsky is the continuation of the stanza principles established in the sphere of Russian romance of the XIX century, based on the correspondence of the internal censuring of a musical composition in accordance with the division of a poetic text into stanzas. Such a correlation between the poetic and musical level in the chamber and vocal compositions of S. Slonimsky is a stable feature of the compositions that are stylistically oriented towards the urban romance of the XIX century, and in the works of other chamber and vocal genres, in which musical and expressive means are used that far exceed the artistic capabilities of urban romance.

\section{BIBLIOGRAPHY}

1. Васина-Гроссман В. Музыка и поэтическое слово в 3 ч. Ч. 1 Ритмика. Москва : Музыка, 1972. 151 с.

2. Васина-Гроссман В. Музыка и поэтическое слово в 3 ч. Ч. 2. Интонация. Ч. 3. Композиция. Москва : Музыка, 1978. 368 с.

3. Васина-Гроссман В. Русский классический романс XIX века. Москва : Академия наук, 1956. 352с.

4. Вольные мысли. К юбилею Сергея Слонимского. Санкт-Петербург : Композитор, 2003. 616 с.

5. Гумилев Л. От Руси к России: очерки этнической истории. Москва : Экопрос, 1992. 336 с. 
6. Новая жизнь традиций в советской музыке: Статьи. Интервью. Москва : Сов. композитор, 1989. 392 с.

7. Осадчая С. Теоретические аспекты изучения православной певческой традиции: история и современность. Монография. Одесса: Астропринт, 2012. 264 с.

8. Ручьевская Е. О соотношении слова и мелодии в русской камерно-вокальной музыке начала XX века. Русская музыка на рубеже ХХ века. Статьи, сообщения, публикации. Москва ; Ленинград : Музыка, 1966. С. 65-110.

9. Ручьевская Е. Слово и музыка. Ленинград : Музгиз, 1960. 56 с.

10. Слонимский С. Взгляд из предыдущего десятилетия. Интервью с С. Слонимским и А. Шнитке. Музыкальная академия. 1992. № 1. C. $20-26$.

11. Слонимский С. Жизнь - какая она есть. Советская музыка. 1990. № 10. С. 8-10.

12. Черноморская С.Л. Творчество Сергея Слонимского 1990-2000-х годов: эстетика, стиль : диссертация ... кандидата искусствоведения : 17.00.02. Москва, 2010. 316 с.

\section{REFERENCES}

1. Vasina-Grossman, V. (1972) Music and poetic word in 3 parts. Part 1. Rhythmics. M.: Music. [in Russian].

2. Vasina-Grossman, V. (1978) Music and poetic word in 3 parts. Part 2. Intonation. Part 3. Composition. M.: Music. [in Russian].

3. Vasina-Grossman, V. (1956) Russian classical romance of the XIX century. M.: Academy of Sciences. [in Russian].

4. Free thoughts. For the anniversary of Sergei Slonimsky. (2003) Saint Petersburg: Composer. [in Russian].

5. Gumilyov, L. (1992) From Russia to Russia: essays on ethnic history. M.: Ekopros. [in Russian].

6. New life of traditions in Soviet music: Articles. Interview. (1989) M.: Sov. composer. [in Russian].

7. Osadchaya, S. (2012) Theoretical aspects of studying the Orthodox singing tradition: history and modernity. Monograph. Odessa: Astroprint. [in Russian].

8. Ruchievskaya, E. (1966) About the relationship between word and melody in Russian chamber and vocal music of the early XX century. Russian music at the turn of the XX century. Articles, messages, publications. M.; L.: Music. 65-110 p. [in Russian].

9. Ruchievskaya, E. (1960) Word and music. L.: Muzgiz. [in Russian].

10. Slonimsky, S. (1992) A look from the previous decade. Interview with S. Slonimsky and A. Schnittke. Music Academy. № 1. 20-26 p. [in Russian]. 11. Slonimsky, S. (1990) Life - what it is. Soviet music. 1990. № 10. 8-10 p. [in Russian].

12. Chernomorskaya, S. (2010) Works of Sergei Slonimsky during 1990-2000s: aesthetics, style: Dissertation of the Candidate of Art History: 17.00.02. Moscow. [in Russian]. 